\title{
Political Competition and the (In)Effectiveness of Redistribution in a Federation
}

\author{
Ikuho Kochi ${ }^{1} \&$ Raúl Alberto Ponce Rodríguez ${ }^{1}$ \\ ${ }^{1}$ Universidad Autónoma de Ciudad Juárez, Instituto de Ciencias Sociales y Administración, Ciudad Juárez, \\ Chihuahua, México \\ Correspondence: Raúl Alberto Ponce Rodríguez, Universidad Autónoma de Ciudad Juárez, Instituto de Ciencias \\ Sociales y Administración, Heroico Colegio Militar y Av. Universidad No. 3775, Zona Chamizal, zip 32310, \\ Ciudad Juárez, Chihuahua, México. Tel: 52-656-688-3893. E-mail: rponce@uacj.mx
}

Received: February 2, 2013

Accepted: April 3, 2013

Online Published: April 18, 2013

doi:10.5539/ijef.v5n5p75

URL: http://dx.doi.org/10.5539/ijef.v5n5p75

\begin{abstract}
We analyze politico-economic conditions in which the effectiveness of public redistribution might be low in a federation. In our economy, the central government redistributes income while local governments provide a pro poor public good. If local public spending falls due to the ex-post tax-transfer distribution of income engineered by the central government then public redistribution might be less effective in redistributing welfare. In this paper we address this issue. Our main findings are: first, if the party on power represents voters with a labor wage below the average wage and the aggregate net transfer from the redistributive program is negative for residents in the locality then public spending falls in this district. Second, if local governments of all districts are controlled by parties representing voters with high marginal utilities of income and labor wages below the nationwide average wage then public redistribution induces all local governments to reduce spending.
\end{abstract}

Keywords: redistributive effects, efficiency, state and local government, fiscal policy and behavior of agents, elections

\section{Introduction}

Governments of developed and developing economies engage in different programs that seek to redistribute income. While the benefit of public redistribution is a welfare-superior allocation of resources for the society, the literature of public economics has also recognized that redistribution leads to inefficiency costs associated with the response of households to the government's attempt to redistribute income (see Auerbach \& Hines, 2002; Alm, 1996; Gravelle \& Kotlikoff, 1989; Salanié, 2003, among many others). This literature also argues that these inefficiency costs reduce the effectiveness of income redistribution in increasing the welfare of the society and impose a limit to the size of the government's redistributive policy.

In this paper, we are interested in studying the response of local public spending to a change in the redistributive policy of the central government. This is an interesting issue that might be central to explain the effectiveness of the redistributive policy of the federal government for an economy with a federation. To see this, it is sufficient to recognize that public redistribution changes the distribution of welfare in the society by increasing (reducing) the full income of poor (rich) families but this policy is also likely to affect local public spending. One plausible outcome is that local public spending might be pro poor and it might fall as a result of a policy by the central government that seeks to redistribute income. In this case, the redistributive policy of the central government increases the well being of poor familes but a fall in local public spending reduces it. Hence, the net welfare of the redistributive policy of the central government is ambiguous.

The objective of this paper is to identify political and economic conditions in which the effectiveness of the redistributive policy of the central government might be undermined by the response of local governments. To do so, we develop a political economy model of a federation in which the central government redistributes income and local governments set commodity taxes to provide a pro poor local public good. In this setting, parties are political institutions that represent coalitions of voters who compete to form a local government to implement their ideal fiscal policies. Hence, the response of local governments to the fiscal policy of the central government reflects how income redistribution changes, first, the voters' demand of local spending, since the redistribution of income modifies the budget constraint of the coalition of voters who control the party in power 
in the locality, and second, the redistribution of income changes the demand of private goods and the ability of local governments to raise tax revenue through indirect taxation.

The main findings of our paper are the following: first, the size of the pro poor local public good for an economy with a redistributive linear policy from the central government is lower at least in some district relative the size of the local public good for an economy without a centralized redistributive policy, if the net transfer from the redistributive program is positive for the coalition of voters controlling the party in power (that is to say, the party in office represents a coalition of voters with labor earning abilities below the average earning ability of the economy) and the aggregate net transfer from the redistributive policy is negative for residents of this district. In this case, a linear redistributive policy from the central government might fail to redistribute welfare in a focalized district. Second, if local governments of all districts are controlled by parties representing individuals with sufficiently high marginal utilities of income and labor earning abilities below the nationwide average labor earning ability then the redistributive program of the federal government induces all local governments to reduce the provision of local public goods. In this case, the redistributive policy of the central government can be universally ineffective in redistributing welfare in the federation.

The implication of these equilibriums is that the redistributive policy of the central government might cause significant inefficiency costs in the allocation of resources (due to the individuals' response to tax and transfers policies) while the benefit of public redistribution might be small due to the response of local governments in the provision of public goods. Hence, the net benefits of the redistributive policy of the federal government might be more limited than previously thought. Finally, in this paper we identify empirically verifiable hypothesis on the effects of a linear redistributive program of the central government on the spending policies of sub-national governments.

The rest of the paper is structured as follows: section 2 includes the literature review. Section 3 characterizes the politico-economic equilibrium for this economy and the size of local public spending. The comparative analysis of the distribution of local public spending for economies with and without redistribution is conducted in section 4 . Section 5 concludes.

\section{Literature Review}

One of the main areas of research in public economics deals with the inefficiency costs from taxation and public spending (see for instance, Auerbach \& Hines 2002; Auerbach \& Slemrod 1997; Gravelle \& Kotlikoff 1989; Salanié 2003, among many others). Our paper is related to this literature by studying how the tax and spending policies of the central government modify the gains from the fiscal exchange that local governments offer to their residents. In our economy, the redistributive policy of the central government not only changes the residents' relative prices between private versus local public goods and the relative prices between local public goods and redistributive spending but also affects the political response of the coalitions of voters who control local governments (this is the focus of our paper). We argue that the behavioral effects from public redistribution on local governments are central in explaining how effective the central government can be in redistributing welfare.

Our analysis is also related to the theory on coordination failures in a federation such as the studies of fiscal vertical and horizontal externalities. This theory highlights that the strategic interaction between self-interested governments might lead to a Pareto inefficient allocation of public resources in a federation due to presence of horizontal and vertical fiscal externalities. For the case of horizontal externalities, Wildasin (1986) argues that state governments ignore the effect of local taxes on other jurisdictions. Hence, in presence of mobility of households and firms, state governments will overestimate the marginal costs of public funds leading to too little sub-national spending. For the case of vertical fiscal externalities, the basic argument in Johnson (1988), Boadway and Keen (1996), Dahlby (1994), Boadway, Marchand and Vigneault (1998), and more recently Rizzo (2008) and Dahlby and Wilson (2003), is that the federal and sub-national governments might not take into account how their policies affect the policy of vertically differentiated governments. Therefore, these governments will underestimate the marginal costs of public funds associated with raising tax revenue leading to too much public spending.

Our paper is relevant to the fiscal vertical externality theory since our analysis suggests that, contingent to the identity of the party winning the election, there are conditions in which the fiscal vertical externality might not only lead to too much spending at the local level but also to too little local spending. These outcomes follow from the fact that the impact of the redistributive policy of the central government on sub-national spending and tax policies is contingent to the characteristics (preferences and earning abilities) of the decisive coalition of voters controlling the party on power. In particular, we provide a model of partisan electoral politics that highlights the role of local 
elections in aggregating the heterogeneous preferences of individuals over fiscal policy. In our analysis elections do not affect the parties' design of fiscal policy. However, voters choose between the divergent platforms of two parties. In addition, the redistribution of income engineered by the policy of the central government changes the demand of private goods and the ability of local governments to raise tax revenue through indirect taxation.

In this context, there are, at least two types of equilibriums of interest: first, the case of coordination failures between sub-national governments and the central government (in which case public redistribution leads to too little public spending at the local level and in this case public redistribution might not effective). Second, the case of welfare-dominant allocations where the performance of local governments could increase the return of the redistributive policy of the central government (we have left this case for future research).

In particular, our paper contributes to the literature on coordination failures in a federation by identifying conditions in which a linear redistributive policy might fail to redistribute welfare in a focalized district or it is universally ineffective in redistributing welfare in the federation. That is, our paper shows that if the party that wins the local election in district $i$ represents a coalition of voters with labor earning abilities below the average earning ability of the economy and the aggregate net transfer from the redistributive program is negative for residents in this locality, then the size of local public spending in this district falls. Moreover, if parties representing voters with sufficiently high marginal utilities of income and labor earning abilities below the nationwide average earning ability win the local elections in all districts then the redistributive program of the government induces all local governments to reduce local spending. The implication of these outcomes is that the attempt of the central government to redistribute welfare from the rich to the poor through a linear redistributive program could be ineffective.

\section{Redistribution and the Decentralized Provision of Local Public Goods}

In this section we study the role of politics on local elections in determining the response of local governments to changes in the distribution of income promoted by the redistributive policy of the central government. Our economy is constituted by a central government and two sub-national governments (associated with localities or districts 1 and 2). The central and sub-national governments have different tasks mandated by the constitution of the country. We take as given these constitutional mandates. Local governments provide local public goods (such as local security, education, bridges, parks, trash recollection, etc.) and the central government is engaged only in the redistribution of income. This structure of the responsibilities of the central and sub-national governments has empirical support in many developed and developing countries (see Ter-Minassian, 1997).

\subsection{Preferences and Constraints of Residents}

The budget constraint and preferences of a resident of locality $i=\{1,2\}$ on local public goods are given by:

$$
\begin{gathered}
v^{i}\left(t^{i}, g^{i}, n^{i}\right) \\
\text { subject to } g^{i}=t^{i} \int_{\forall n^{i}} h^{i}\left(n^{i}\right) x^{* i}\left(t^{i}, \tau, T, n^{i}\right) d n^{i}
\end{gathered}
$$

Where the indirect utility is $v^{i}\left(t^{i}, g^{i}, n^{i}\right)=\operatorname{Max}\left\{\mu^{* i}=\ln \left(x^{* i}\right)+\ln \left(1-\ell^{* i}\right)+g^{i}\right\}$ subject to $q^{i} x^{* i}=$ $n^{i} \ell^{* i}(1-\tau)+T$, and it characterizes the indirect preferences of a resident type $n^{i}$ of district $i$ on feasible local public goods. Direct preferences on private consumption, $x^{i}$, the local public good, $g^{i}$, and leisure $\left(1-\ell^{i}\right)$ are defined by $\mu^{i}\left(x^{i},\left(1-\ell^{i}\right), g^{i}\right)=\ln \left(x^{i}\right)+\ln \left(1-\ell^{i}\right)+g^{i}$. The individual's budget constraint is $q^{i} x^{i}=$ $n^{i} \ell^{i}(1-\tau)+T$ where $q^{i}=1+t^{i}$ is the consumer's price of the private good (we have normalized the producer's price to one) and $t^{i}$ is a tax on private consumption imposed by the local government of district $i$ on its residents.

Moreover, $n^{i} \ell^{i}(1-\tau)$ is the individual's after-tax labor income, $\ell^{i}$ is the supply of labor, the parameter $n^{i}$ is exogenous and represents the ability of the individual to earn labor income (the term $n^{i}$ can be interpreted as a competitive wage on labor services), $\tau$ is the federal tax on labor income, and $T$ is a per capita transfer from the central government to a resident of district $i$. The parameters $\tau$ and $T$ represent a linear redistributive program of the central government. The distribution of labor skills in each district is determined by the density $h^{i}\left(n^{i}\right)>$ $0: n^{i} \in\left[n_{\min }^{i}, n_{\text {max }}^{i}\right] \forall i$ such that the cumulative density in district $i, H^{i}\left(n^{i}\right)$, satisfies $H^{i}\left(n^{i}\right)=\int_{\forall n^{i}} h^{i}\left(n^{i}\right) d n^{i}=N^{i} / N^{T}$ where $N^{i}$ is the population in district $i=\{1,2\}$ and $N^{T}=N^{1}+N^{2}$.

Condition (2) is the budget constraint of the local government in district $i$. Local public goods are financed by a commodity tax rate $t^{i}$ on purchases of the private good by local residents. Tax revenue of the local government in district $i$ is given by $R\left(t^{i}\right)=t^{i} \int_{\forall n^{i}} h^{i}\left(n^{i}\right) x^{* i}\left(t^{i}, \tau, T, n^{i}\right) d n^{i}$. (Note 1). Moreover, we consider the following: 


$$
\int_{\forall n^{1}} h^{1}\left(n^{1}\right) n^{1} d n^{1}>\int_{\forall n^{2}} h^{2}\left(n^{2}\right) n^{2} d n^{2}
$$

The assumption in $\boldsymbol{A 1}$ simply characterizes the heterogeneity of the ability of earning labor income between residents of districts 1 and 2 . Without loss of generality, we assume that the average earning ability of residents of district 1 is higher than that of residents of district 2. Now we characterize the optimal labor supply and consumption of private goods for individuals in this economy.

Proposition 1. The optimal supply of labor and consumption of the private good for individual type $n^{i}$ in district $i$ are given by:

$$
\ell^{* i}\left(\tau, T, n^{i}\right)=\frac{1}{2}-\frac{T}{2 n^{i}(1-\tau)}
$$

And

$$
x^{* i}\left(t^{i}, \tau, T, n^{i}\right)=\frac{n^{i}(1-\tau)}{2 q^{i}}+\frac{T}{2 q^{i}}
$$

\section{Proof}

Results follow by defining the following maximization problem for individual type $n^{i}: \operatorname{Max} \delta^{i}=\ln \left(x^{i}\right)+$ $\ln \left(1-\ell^{i}\right)+g^{i}+\alpha^{i}\left\{n^{i} \ell^{i}(1-\tau)+T-q^{i} x^{i}\right\}$ where $\alpha^{i}$ is a Lagrange multiplier. Obtain $\partial \delta^{i} / \partial x^{i}=0$ for $x^{* i}>0, \partial \delta^{i} / \partial \ell^{i}=0$ for $\ell^{* i}>0$, and $\partial \delta^{i} / \partial \alpha^{i}=0$ for $\alpha^{* i}>0$. Re-arrange terms to show that $\ell^{* i}=\frac{1}{2}-$ $\frac{T}{2 n^{i}(1-\tau)}$ and $x^{* i}=\frac{n^{i}(1-\tau)}{2 q^{i}}+\frac{T}{2 q^{i}}$.

\subsection{Political Equilibrium and the Design of Local Public Spending}

In this economy, the heterogeneity of the individuals' labor earning abilities leads to conflicts among voters of the same district over the size of local public spending. Therefore, the social choice problem for local governments is to find the society's ideal size of local public goods. The political institution that solves this social choice problem is a local election in which candidates of political parties propose the size of the government's spending and voters elect a public official. The party winning the election by simple majority in the locality has the right to design and implement the party's platform on local public spending.

We assume that parties have preferences over the size of the government's spending. Wittman $(1973,1983)$ argues that parties might be controlled by some coalition of voters of the electorate. Because voters have preferences over economic policies, parties want to design and implement the policy on local public goods that maximizes the preferences of the representative coalition of voters controlling the party. (Note 2). In this setting, we are interested in the response of local governments to the fiscal policy of the central government. In particular, we argue that income redistribution affects the ideal policy of parties over local spending by changing the total income of the coalition of voters controlling the party on power and by changing the distribution of total income and private consumption of residents in the locality, which in turn, affects both the demand of residents of public goods and the ability of local governments to raise tax revenue. (Note 3 )

For this economy the politico-economic equilibrium is characterized by the sub-game perfect Nash equilibrium shown in definition 1. For this characterization, consider a cumulative distribution function given by $\boldsymbol{\Omega}:\left\{\chi^{i}\left(n^{i}\right)\right\}_{\forall n^{i}} \rightarrow[0,1]$, where $\boldsymbol{\Omega}$ is a non decreasing function of the sequence $\left\{\chi^{i}\left(n^{i}\right)=v^{L i}\left(t^{* L i}, g^{* L i}, n^{i}\right)-\right.$ $\left.v^{R i}\left(t^{* R i}, g^{* R i}, n^{i}\right)\right\}_{\forall n^{i}}$, where $\chi^{i}\left(n^{i}\right)$ reflects a rational choice of the vote for individual type $n^{i}$ in the election of locality $i$, and $v^{L i}\left(t^{* L i}, g^{* L i}, n^{i}\right)$ is the welfare of individual type $n^{i}$ if party $L$ in district $i$ wins the local election and implements policies $t^{* L i}, g^{* L i}$ in the district. A similar interpretation is given to $v^{R i}\left(t^{* R i}, g^{* R i}, n^{i}\right)$.

Definition 1 The electoral-economic equilibrium for an economy with a decentralized provision of local public goods in districts $i=1,2$ and parties with preferences on local public spending is characterized as follows: In the first scenario nature announces the type of coalitions of voters who run parties $Z=\{L, R\}$ which in this case they are characterized by $n^{Z i} \forall Z=\{L, R\}, \forall i$. The nature's move is common knowledge. In the second scenario two parties, denoted as parties $\mathrm{L}$ and $\mathrm{R}$, announce local tax and spending policy platforms. In the third stage, citizens vote in each locality for a party based on the type of spending policies that these parties would implement if they win the election. (Note 4) In the fourth stage, the party winning the election in each district takes control of the government and the policies $g^{* L i}, t^{* L i}$ or $g^{* R i}, t^{* R i}$ are implemented. Formally:

1) In the second scenario of the local election in district $i$, parties announce policies that maximize the party's 
preferences for local public spending $g^{* Z i}, t^{* Z i} \forall Z=\{L, R\}, \forall i$ : (Note 5)

$$
\begin{gathered}
g^{* Z i}, t^{* Z i} \in \operatorname{argmax} v^{Z i}\left(t^{i}, g^{i}, n^{Z i}\right) \forall Z, \forall i \\
\text { subject to } g^{* Z i}=t^{* Z i} \int_{\forall n^{i}} h^{i}\left(n^{i}\right) x^{* i}\left(t^{* Z i}, \tau, T, n^{i}\right) d n^{i}
\end{gathered}
$$

2) In the third scenario of the local election, the voter type $n^{i}$ in district i votes

$$
\text { For party L if } \chi^{i}\left(n^{i}\right)=v^{L i}\left(t^{* L i}, g^{* L i}, n^{i}\right)-v^{R i}\left(t^{* R i}, g^{* R i}, n^{i}\right)>0
$$

For party $R$ if $\chi^{i}\left(n^{i}\right)<0$

3) Moreover, $\boldsymbol{\Omega}$ is a non decreasing cumulative distribution of the sequence $\left\{\chi^{i}\left(n^{i}\right)\right\}_{\forall} n^{i}$. Therefore, in the fourth scenario, if there exists a majority of voters $n^{i} \in\left[n_{\min }^{i}, n_{\max }^{i}\right]: \chi^{i}\left(n^{i}\right)>0$ then it is satisfied

$$
\boldsymbol{\Omega}\left(\forall n^{i} \in\left[n_{\text {min }}^{i}, n_{\text {max }}^{i}\right]: \chi^{i}\left(n^{i}\right)>0\right)>1 / 2
$$

In this case party $L$ wins the local election in district $i$ in the fourth scenario and implements $g^{* L i}, t^{* L i}$. In contrast, if

$$
\boldsymbol{\Omega}\left(\forall n^{i} \in\left[n_{\text {min }}^{i}, n_{\text {max }}^{i}\right]: \chi^{i}\left(n^{i}\right)<0\right)>1 / 2
$$

then party $R$ wins the local election in district $\mathrm{i}$ and implements $g^{* R i}, t^{* R i}$.

\subsection{The Distribution of Local Public Goods in a Federation}

In this section we characterize the general case of the decentralized provision of local public spending when the redistributive instruments of the central government are $\tau \geq 0$ and $T \geq 0$.

Proposition 2 With a coalition of voters type $n^{Z i}$ controlling party $Z=\{L$ or $R\}$, the ideal size of the local public good provided in district $i$ by party $Z$ is:

$$
\begin{gathered}
g^{* Z i}\left(n^{Z i}\right)=\frac{1}{2}\left\{\int_{\forall n^{i}} h^{i}\left(n^{i}\right) n^{i} d n^{i}-\frac{n^{Z i}}{M R S_{g^{Z i}-\alpha^{Z i}}}\right\} \\
+\frac{1}{2}\left\{T H^{i}\left(n^{i}\right)-\tau \int_{\forall n^{i}} h^{i}\left(n^{i}\right) n^{i} d n^{i}-\left\{\frac{T-\tau n^{Z i}}{M R S_{g^{Z i}-\alpha^{Z i}}}\right\}\right\} \forall Z, \forall i
\end{gathered}
$$

Where $E\left[n^{i}\right]=\int_{\forall n^{i}} h^{i}\left(n^{i}\right) n^{i} d n^{i}$ is the average labor earning ability of residents of district $i, n^{Z i}$ and $M R S_{g^{z i}-\alpha} z i$ are, correspondingly, the labor earning ability and the marginal rate of substitution between the local public good and income of the coalition of voters controlling party $Z$ in district $\mathrm{i}$, and $H^{i}\left(n^{i}\right)=$ $\int_{\forall n^{i}} h^{i}\left(n^{i}\right) d n^{i}=N^{i} / N^{T}$ is the density of the population of district i.

\section{Proof}

The problem for party $Z=\{L$ or $R\}$ in district $i$ is to choose $t^{* Z i}, g^{* Z i}$ to

$$
\begin{gathered}
\operatorname{Max} v^{Z i}\left(t^{i}, g^{i}, n^{Z i}\right) \\
\text { subject to } g^{i}=t^{i} \int_{\forall n^{i}} h^{i}\left(n^{i}\right) x^{* i}\left(t^{i}, \tau, T, n^{i}\right) d n^{i}
\end{gathered}
$$

Where

$$
\begin{gathered}
v^{Z i}\left(t^{i}, g^{i}, n^{Z i}\right)= \\
=\operatorname{Max}\left\{\ln \left(x^{* Z i}\right)+\ln \left(1-\ell^{* Z i}\right)+g^{Z i} s t: q^{i} x^{* Z i}=n^{i} \ell^{* Z i}(1-\tau)+T\right\}
\end{gathered}
$$

Define $\gamma^{Z i}$ as follows:

$$
\gamma^{Z i}=v^{Z i}\left(t^{Z i}, g^{i}, n^{Z i}\right)+\lambda^{Z i}\left\{g^{Z i}-t^{Z i} \int_{\forall n^{i}} h^{i}\left(n^{i}\right) x^{* i}\left(t^{Z i}, \tau, T, n^{i}\right) d n^{i}\right\}
$$

The first order conditions for the party's policy problem are:

$$
\frac{\partial \gamma^{Z i}}{\partial t^{Z i}}=\frac{\partial v^{Z i}}{\partial t^{Z i}}-\lambda^{Z i}\left\{\int_{\forall n^{i}} h^{i}\left(n^{i}\right) x^{* i}\left(t^{i}, \tau, T, n^{i}\right)+t^{* Z i} \int_{\forall n^{i}} h^{i}\left(n^{i}\right) \frac{\partial x^{* i}}{\partial t^{Z i}} d n^{i}\right\}=0
$$

And

$$
\frac{\partial \gamma^{Z i}}{\partial g^{Z i}}=\frac{\partial v^{Z i}}{\partial g^{Z i}}+\lambda^{Z i}=0
$$


Define $q^{* Z i}=1+t^{* Z i}$ and use (4) to express

$$
\partial v^{Z i} / \partial t^{Z i}=-\alpha^{Z i} x^{* i}\left(t^{i}, \tau, T, n^{i}\right)=-\alpha^{Z i}\left\{n^{Z i}(1-\tau) / 2 q^{* Z i}+T / 2 q^{* Z i}\right\}
$$

Moreover,

$$
\begin{gathered}
M R S_{g^{Z i}-\alpha^{Z i}}=\frac{\partial v^{Z i}}{\partial g^{Z i}} / \alpha^{Z i}=1 / \alpha^{Z i} \\
\int_{\forall n^{i}} h^{i}\left(n^{i}\right) x^{* i}\left(t^{i}, \tau, T, n^{i}\right) d n^{i}=\frac{(1-\tau)}{2 q^{* Z i}} \int_{\forall n^{i}} h^{i}\left(n^{i}\right) n^{i} d n^{i}+\frac{T}{2 q^{* Z i}} H^{i}\left(n^{i}\right) \\
H^{i}\left(n^{i}\right)=\int_{\forall n^{i}} h^{i}\left(n^{i}\right) d n^{i}=N^{i} / N^{T} \\
\int_{\forall n^{i}} h^{i}\left(n^{i}\right) \frac{\partial x^{* i}}{\partial t^{Z i}} d n^{i}=-\frac{(1-\tau)}{2\left(q^{* Z i}\right)^{2}} \int_{\forall n^{i}} h^{i}\left(n^{i}\right) n^{i} d n^{i}-\frac{T}{2\left(q^{* Z i}\right)^{2}} H^{i}\left(n^{i}\right)
\end{gathered}
$$

Use conditions (10) to (15) into (9) and re-arrange terms to show that $t^{* Z i} / q^{* Z i}$ is given by

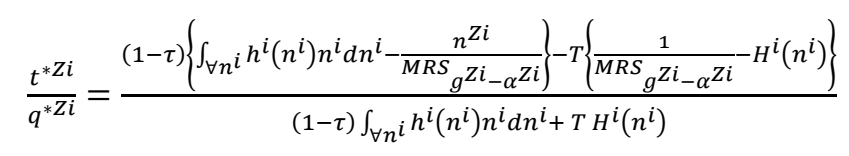

From the government's budget constraint

$$
\begin{gathered}
g^{* Z i}=t^{* Z i} \int_{\forall n^{i}} h^{i}\left(n^{i}\right) x^{* i}\left(t^{* Z i}, \tau, T, n^{i}\right) d n^{i} \\
g^{* Z i}=\frac{1}{2} \frac{t^{* Z i}}{q^{* Z i}}\left\{(1-\tau) \int_{\forall n^{i}} h^{i}\left(n^{i}\right) n^{i} d n^{i}+T H^{i}\left(n^{i}\right)\right\}
\end{gathered}
$$

Use (16) into (18) to show that the platform of party $Z$ on the local public good of district $i, \forall i$, is given by

$$
\begin{gathered}
g^{* Z i}\left(n^{Z i}\right)=\frac{1}{2}\left\{\int_{\forall n^{i}} h^{i}\left(n^{i}\right) n^{i} d n^{i}-\frac{n^{Z i}}{M R S_{g^{Z i}-\alpha} Z i}\right\} \\
+\frac{1}{2}\left\{T H^{i}\left(n^{i}\right)-\tau \int_{\forall n^{i}} h^{i}\left(n^{i}\right) n^{i} d n^{i}-\left\{\frac{T-\tau n^{Z i}}{M R S_{g^{Z i}-\alpha} Z i}\right\}\right\} \forall Z, \forall i
\end{gathered}
$$

Condition (5) says that the ideal size of the local public good for party $Z$ in district $i$ depends positively on the difference between the average labor income in the locality and a normalized income of the coalition of voters controlling party $Z$, that is $\left\{\int_{\forall n^{i}} h^{i}\left(n^{i}\right) n^{i} d n^{i}-\frac{n^{Z i}}{M R S_{g^{Z i}} \alpha_{-\alpha}}\right\}$, on whether the locality is a net winner or loser of the redistributive program of the central government, this term is $\left\{T H^{i}\left(n^{i}\right)-\tau \int_{\forall n^{i}} h^{i}\left(n^{i}\right) n^{i} d n^{i}\right\} \geq 0$ where $T H^{i}\left(n^{i}\right)$ represent the aggregate transfers from the redistributive program to residents of locality $i$ while $\tau \int_{\forall n^{i}} h^{i}\left(n^{i}\right) n^{i} d n^{i}$ are the aggregate tax payments of residents of the district that finance the redistributive program of the central government. Finally, $g^{* Z i}\left(n^{Z i}\right)$, also depends on whether the coalition that controls party $Z$ in district $i$ is a net winner or loser from the redistributive program of the central government, this term is $\left\{T-\tau n^{Z i}\right\} \geq 0$. (Note 6$)$

The comparative analysis also suggests the following:

Proposition 3 For a large economy, the ideal size of local public spending is a non increasing function of the voter's earning ability, that is for all $\breve{n}^{i}, \dot{n}^{i} \in\left[n_{\text {min }}^{i}, n_{\text {max }}^{i}\right]: \breve{n}^{i} \geq \dot{n}^{i}$ then $g^{*}\left(\breve{n}^{i}\right) \leq g^{*}\left(\dot{n}^{i}\right)$ where $g^{*}\left(\breve{n}^{i}\right)$ and $g^{*}\left(\dot{n}^{i}\right)$ are the ideal size of local public spending of voters with earning abilities $\check{n}^{i}$ and $\dot{n}^{i}$.

In addition, transfers, $T$, tend to increase the size of the local public good in district $i$ when

i. The density of the population of the district is high relative the overall population of the economy, and (or)

ii. The decisive coalition of voters controlling the party on office has a sufficiently low marginal utility of income (i.e., a high willingness to pay for the local public good).

Moreover, an increase in the labor income tax, $\tau$ reduces the size of the local public good in district $i$ when

iii. The labor earning ability of the average voter in district $i$ is sufficiently high, and (or)

iv. The decisive coalition of voters controlling the party on office has a sufficiently low marginal utility of income (i.e., a high willingness to pay for the local public good), and (or) 
$\mathrm{v}$. The labor earning ability of the decisive coalition of voters controlling the party on office on district $i$ is sufficiently low.

\section{Proof}

The first part of the proposition states that for all $\check{n}^{i}, \dot{n}^{i} \in\left[n_{\text {min }}^{i}, n_{\text {max }}^{i}\right]: \check{n}^{i} \geq \dot{n}^{i}$ then $g^{*}\left(\breve{n}^{i}\right) \leq g^{*}\left(\dot{n}^{i}\right)$. This result follows directly from the fact that we can generalize condition (5) for any voter in every district. Hence, $\forall n^{i} \in\left[n_{\text {min }}^{i}, n_{\text {max }}^{i}\right]$, the ideal size of local public spending for a voter type $n^{i}, g^{*}\left(n^{i}\right)$, is given by $g^{*}\left(n^{i}\right)=\frac{1}{2}\left\{E\left[n^{i}\right]-\frac{n^{i}}{M R S_{g-\alpha} n i}+T H^{i}\left(n^{i}\right)-\tau E\left[n^{i}\right]-\left\{\frac{T-\tau n^{i}}{M R S_{g-\alpha} n i}\right\}\right\} \quad$ where $\quad E\left[n^{i}\right]=\int_{\forall n^{i}} h^{i}\left(n^{i}\right) n^{i} d n^{i} . \quad$ It follows that $\partial g^{*}\left(n^{i}\right) / \partial n^{i}=\frac{1}{2}\{1-\tau\}\left\{h^{i}\left(n^{i}\right)-\frac{1}{M R S_{g-\alpha^{n i}}}\right\} \leq 0$ since for a large economy $h^{i}\left(n^{i}\right) \cong 0,\{1-$ $\tau\} \geq 0$, and $M R S_{g-\alpha} n i>0$. Therefore, the ideal size of local public spending is a non increasing function of the voter's earning ability.

Now, recall from (5) that the ideal size of the local public good for party $Z$ in district $i$ is $g^{* Z i}$ :

$$
\begin{gathered}
g^{* Z i}=\frac{1}{2}\left\{\int_{\forall n^{i}} h^{i}\left(n^{i}\right) n^{i} d n^{i}-\frac{n^{Z i}}{M R S_{g^{Z i}-\alpha^{Z i}}}\right\} \\
+\frac{1}{2}\left\{T H^{i}\left(n^{i}\right)-\tau \int_{\forall n^{i}} h^{i}\left(n^{i}\right) n^{i} d n^{i}-\left(\frac{T-\tau n^{Z i}}{M R S_{g^{Z i}-\alpha^{Z i}}}\right)\right\} \forall i
\end{gathered}
$$

It is simple to verify that

$$
\frac{\partial g^{* Z i}}{\partial T}=H^{i}\left(n^{i}\right)-\frac{1}{M R S} g_{g^{Z i}-\alpha^{Z i}} \geq 0
$$

Where $M R S_{g^{Z i}-\alpha^{Z i}}=\frac{\partial v^{Z i}}{\partial g^{Z i}} / \alpha^{Z i}=1 / \alpha^{Z i}$ is the willingness to pay for the local public good by the decisive coalition of voters controlling the party in power. Hence as $M R S_{g^{z i}-\alpha^{Z i}} \rightarrow \infty$ then $\partial g^{* Z i} / \partial T>0$, or if $H^{i}\left(n^{i}\right) \rightarrow 1$ while $M R S_{g^{Z i}-\alpha^{Z i}}$ is sufficiently low then $\partial g^{* Z i} / \partial T>0$. Moreover,

$$
\frac{\partial g^{* Z i}}{\partial \tau}=-\int_{\forall n^{i}} h^{i}\left(n^{i}\right) n^{i} d n^{i}+\frac{n^{Z i}}{M R S_{g^{Z i}-\alpha^{Z i}}} \geq 0
$$

Hence a sufficiently high $\int_{\forall n^{i}} h^{i}\left(n^{i}\right) n^{i} d n^{i}$, and (or) $M R S_{g^{Z i}-\alpha^{Z i}} \rightarrow \infty$, and (or) a sufficiently low $n^{Z i}$ then $\partial g^{* Z i} / \partial \tau<0$.

Proposition 2 characterizes the set of politically feasible local public goods in district $i$ and proposition 3 provides a comparative static analysis of $g^{* Z i}$. In particular, proposition 3 says that an increase in the size of transfers from the redistributive program of the federal government does not necessarily increases the provision of the local public in district $i$. To see this, condition (21) shows that an increase in $T$ might lead to a higher provision of the local public good when the density of the population of the district is high relative the overall population of the economy, and (or), the decisive coalition of voters controlling the party on power has a sufficiently high willingness to pay for the local public good.

A higher density of the population of the district means that a higher share of the resources of the redistributive program is allocated to the district. This in turn increases the demand of residents for private goods, the district's tax collection, and the provision of the local public good. Simultaneously, a higher transfer of the central government increases the full income of the decisive coalition of voters controlling the party on office and it induces the members of the party to substitute private goods for public goods. Hence, this effect of the redistributive program on the coalition of voters controlling the party on office tends to reduce the provision of the local public good.

Proposition 3 also says that the marginal increase in $g^{* Z i}$ due to an increase of the federal income tax depends negatively on the difference between the average labor earning ability in the locality and a normalized income of the coalition of voters controlling party $Z$ in office (see condition 22). Hence, an increase of the federal income tax tends to reduce the provision of the local public good in district $i$ if: first, the labor earning ability of the average voter is high (because in this case the district is a net contributor to the redistributive program and the federal program induces an aggregate negative income effect on residents that reduces the district's tax revenue). Second, the decisive coalition of voters controlling the party on power has a sufficiently high willingness to pay for the 
local public good. Third, the labor earning ability of the decisive coalition of voters controlling the party on power on district $i$ is sufficiently low.

\subsection{The Divergence of the Parties' Policies}

In proposition 4 we identify conditions that guarantee that party $L$ or $R$ wins the local election in each district by simple majority. We also identify the sources of the divergence of the parties' fiscal policies at the political equilibrium. Hence propositions 2 and 4 represent a set of politico-economic conditions that identify the design and implementation of local public spending.

Proposition 4 Assume $\tau \geq 0, T \geq 0$, if

Condition $4.1 \quad n^{R i}>n^{L i}, \alpha^{R i}<\alpha^{L i}$ such that $\alpha^{R i} n^{R i}>\alpha^{L i} n^{L i}$ then $\left\{\frac{\alpha^{R i} n^{R i}-\alpha^{L i} n^{L i}}{\alpha^{L i}-\alpha^{R i}}\right\} \geq\left\{\frac{T}{1-\tau}\right\} \quad$ implies $\hat{g}^{* L i} \underset{<}{<} \hat{g}^{* R i}$

Moreover, if

$$
\boldsymbol{\Omega}\left(\forall n^{i} \in\left[n_{\text {min }}^{i}, n_{\text {max }}^{i}\right]: \chi^{i}\left(n^{i}\right)>0\right)>1 / 2
$$

Then party $L$ wins the local election in district $\mathrm{i}$ and implements $\hat{g}^{* L i}$. In contrast, if

$$
\boldsymbol{\Omega}\left(\forall n^{i} \in\left[n_{\text {min }}^{i}, n_{\text {max }}^{i}\right]: \chi^{i}\left(n^{i}\right)<0\right)>1 / 2
$$

Then party $R$ wins the local election in district $\mathrm{i}$ and implements $\hat{g}^{* R i}$. (Note 7)

\section{Proof}

The equilibrium condition (5) means that

$$
\begin{aligned}
& \hat{g}^{* L i}-\hat{g}^{* R i}=\frac{1}{2}\left\{\frac{T-(1-\tau) n^{R i}}{M R S_{g^{R i}-\alpha^{R i}}}-\frac{T-(1-\tau) n^{L i}}{M R S_{g^{L i}-\alpha^{L i}}}\right\}= \\
& =\frac{1}{2}\left\{\left(\alpha^{R i}-\alpha^{L i}\right) T-(1-\tau)\left\{\alpha^{R i} n^{R i}-\alpha^{L i} n^{L i}\right\}\right\}
\end{aligned}
$$

By (1), $n^{R i}>n^{L i}, \alpha^{R i}<\alpha^{L i} \Leftrightarrow \alpha^{R i} n^{R i}>\alpha^{L i} n^{L i}$. (Note 8). Hence condition 4.1 implies that if $\left\{\frac{\alpha^{R i} n^{R i}-\alpha^{L i} n^{L i}}{\alpha^{R i}-\alpha^{L i}}\right\} \geq\left\{\frac{T}{1-\tau}\right\} \Rightarrow \hat{g}^{* L i} \underset{<}{<} \hat{g}^{* R i}$. Moreover, $\boldsymbol{\Omega}$ is a non decreasing cumulative distribution of the sequence $\left\{\chi^{i}\left(n^{i}\right)\right\}_{\forall n^{i}}$. Therefore, if there exists a majority of voters $n^{i} \in\left[n_{\min }^{i}, n_{\max }^{i}\right]: \chi^{i}\left(n^{i}\right)>0$ then it is satisfied

$$
\boldsymbol{\Omega}\left(\forall n^{i} \in\left[n_{\text {min }}^{i}, n_{\text {max }}^{i}\right]: \chi^{i}\left(n^{i}\right)>0\right)>1 / 2
$$

In this case party $L$ wins the local election in district $i$ and implements $g^{* L i}, t^{* L i}$. In contrast, if $\boldsymbol{\Omega}\left(\forall n^{i} \in\right.$ $\left.\left[n_{\text {min }}^{i}, n_{\text {max }}^{i}\right]: \chi^{i}\left(n^{i}\right)<0\right)>1 / 2$ then party $R$ wins the local election in district $i$ and implements $g^{* R i}, t^{* R i}$. In proposition 4 , the term $\alpha^{Z i} n^{Z i} \forall Z, \forall i$ can be interpreted as elasticity between welfare and wage. (Note 9). With $\tau=T=0, \alpha^{R i} n^{R i} \underset{<}{<} \alpha^{L i} n^{L i}$ implies $\hat{g}^{* L i} \underset{<}{<} \hat{g}^{* R i}$. The divergence of the parties' policies is the result of the heterogeneity of the voters' earning abilities and preferences. Since the redistributive policy of the central government tends to equalize full income then proposition 4 says that, the divergence of the parties' policies when $\tau>0, T>0$ are related with the difference between the normalized elasticity of welfare-wage between the left and right party characterized in condition 4.1. This difference must be higher or lower than a normalized transfer from the central government given by $T /(1-\tau)$. Therefore, $\left\{\frac{\alpha^{R i} n^{R i}-\alpha^{L i} n^{L i}}{\alpha^{L i}-\alpha^{R i}}\right\} \geq\left\{\frac{T}{1-\tau}\right\}$ implies $\hat{g}^{* L i} \stackrel{<}{<} \hat{g}^{* R i}$.

\section{Effect of Public Redistribution on Local Public Spending}

The equilibrium conditions in (5), (23) and (24) allow a comparative analysis on the size and distribution of local public goods for economies with and without a linear redistributive policy by the central government. In this section, proposition 5 identifies the size of local public goods provided by sub-national governments for the special case of an economy with $\tau=T=0$. Proposition 6 shows that the effects of the redistributive policy on the provision of local public goods by sub-national governments depend on: first, how the linear redistributive policy affects both the distribution of full income of local residents and the budget constraint of the local government, and second, on the net effect of the redistributive policy on full income of the coalition of voters controlling the party that rules the local government.

As we mentioned before, the net transfer from the redistributive program for the voter represented by the party in 
office in district $i$ is $T-\tau n^{Z i}$ and the aggregate net transfer for residents in the district is $T H^{i}\left(n^{i}\right)-$ $\tau \int_{\forall n^{i}} h^{i}\left(n^{i}\right) n^{i} d n^{i}$. Moreover, we define the size of the local public good in district $i$ for an economy with public redistribution is, $g^{* Z i}$, while the size of the public good for an economy without a centralized redistributive policy is $\hat{g}^{* Z i}$.

Proposition 5 Consider the case in which the federal government does not redistribute income. In this case, the ideal size of public spending of party $Z=\{L$ or $R\}$ in district $i$ is given by $\hat{g}^{* Z i}$ which satisfies the following:

$$
\hat{g}^{* Z i}=\frac{1}{2}\left\{\int_{\forall n^{i}} h^{i}\left(n^{i}\right) n^{i} d n^{i}-\frac{n^{Z i}}{M R S} g_{g^{Z i}-\alpha^{Z i}}\right\} \forall Z, \forall i
$$

\section{Proof}

The result in (27) follows trivially by imposing $\tau=T=0$ in proposition 2 .

Proposition 6 The redistributive linear policy from the central government induces the local government of district $i$ to produce $g^{* Z i}: g^{* Z i}<\hat{g}^{* Z i}$, if

Condition $6.1 T-\tau n^{Z i}>0$

And

Condition 6.1 $T H^{i}\left(n^{i}\right)-\tau \int_{\forall n^{i}} h^{i}\left(n^{i}\right) n^{i} d n^{i}<0$

\section{Proof}

From (5), $g^{* Z i}$ is given by:

$$
\begin{gathered}
g^{* Z i}=\frac{1}{2}\left\{\int_{\forall n^{i}} h^{i}\left(n^{i}\right) n^{i} d n^{i}-\frac{n^{Z i}}{M R S_{g^{Z i}-\alpha^{Z i}}}\right\} \\
+\frac{1}{2}\left\{T H^{i}\left(n^{i}\right)-\tau \int_{\forall n^{i}} h^{i}\left(n^{i}\right) n^{i} d n^{i}-\left(\frac{T-\tau n^{Z i}}{M R S_{g^{Z i}-\alpha^{Z i}}}\right)\right\} \forall i
\end{gathered}
$$

From (27), $\hat{g}^{* Z i}=\frac{1}{2}\left\{\int_{\forall n^{i}} h^{i}\left(n^{i}\right) n^{i} d n^{i}-\frac{n^{Z i}}{M R S_{g^{Z i}-\alpha} Z i}\right\} \forall i$. Hence

$$
g^{* Z i}-\hat{g}^{* Z i}=\frac{1}{2}\left\{T H^{i}\left(n^{i}\right)-\tau \int_{\forall n^{i}} h^{i}\left(n^{i}\right) n^{i} d n^{i}-\left\{\frac{T-\tau n^{Z i}}{M R S_{g^{Z i} i_{-\alpha} Z i}}\right\}\right\} \forall i
$$

Since $\alpha^{Z i} \in \mathbb{R}_{+} \Rightarrow M R S_{g^{Z i}-\alpha^{Z i}} \in \mathbb{R}_{+}$. Therefore, conditions 6.1 and 6.2 imply $g^{* Z i}<\hat{g}^{* Z i}$.

In this economy the redistributive policy of the central government provides a positive net transfer to any voter with a labor earning ability that is lower to the average labor earning ability of the economy. (Note 10). This implies two (in some occasions conflicting) outcomes that explain the final effect of public redistribution on the local provision of public goods. First, if the coalition of voters controlling the local government has a labor earning ability lower than the average labor earning ability of the economy then the redistributive program increases the after tax-transfer income and private consumption of this coalition of voters. This in turn, increases the party's political costs of providing a local public good since the tax burden of the coalition of voters controlling the party on power increases. As a result, the demand of local public goods by the coalition controlling the party on power falls which leads to a lower provision of the local public good in the district. (Note 11)

This outcome depends on the local political process. In this economy, voters have preferences over the size of the local public good in their district. Parties represent different sets of coalitions of voters. This, in turn, determines the political platform on local public goods advanced by parties $L$ and $R$. The first part of proposition 4 says that if a majority of individuals prefer the size of local public goods advanced by party $L$ over the fiscal platform of party $R$ then party $L$ will be elected and this party will be able to implement the desired spending policy of the coalition of voters controlling the elected party. Proposition 4 also identifies conditions in which $\hat{g}^{* L i}>\hat{g}^{* R i}$.

The second outcome of the redistributive policy of the central government on the provision of local public goods is related with the fact that the redistributive policy increases the aggregate after tax-transfer income of residents of the low ability district (district 2) and reduces the aggregate after tax-transfer income of residents of the high ability district (district 1 ). This in turn induces an aggregate negative income effect in the high earning ability district (this effect is condition 6.2 in proposition 6) which reduces both the aggregate private purchases of individuals and the government's tax revenue in this district. As a result, this effect tends to reduce the provision of 
the public good in this district.

Proposition 7 The linear redistributive program of the central government crowds out the provision of local public goods in all districts if

Condition $7.1 T-\tau n^{Z i}>0 \forall Z, \forall i$

Condition $7.2 \exists \theta, \varepsilon,\left\{\alpha^{Z i}\right\}_{\forall n^{i}} \in \mathbb{R}_{++}: \varepsilon \rightarrow 0, \theta \rightarrow 0$ and $\left\{M R S_{g^{Z i}-\alpha^{Z i}}\right\}_{\forall \alpha^{Z i}} \in \mathbb{R}_{++}:\left|M R S_{g^{Z i}-\alpha^{Z i}}-\theta\right|<$ $\varepsilon \forall Z, \forall i$

\section{Proof}

In each district the size of $g^{* Z i} \forall i$ is

$$
g^{* Z i}-\hat{g}^{* Z i}=\frac{1}{2}\left\{T H^{i}\left(n^{i}\right)-\tau \int_{\forall n^{i}} h^{i}\left(n^{i}\right) n^{i} d n^{i}-\frac{\left\{T-\tau n^{Z i}\right\}}{M R S{ }_{g^{Z i}-\alpha} Z i}\right\} \forall Z, \forall i
$$

Conditions (8.1) and (8.2) characterize a set of equilibriums in which $M R S_{g^{Z i}-\alpha^{Z i}}$ is sufficiently low to guarantee $g^{* Z i}<\hat{g}^{* Z i} \forall Z, \forall i$.

Proposition 7 says that if local governments in each district are controlled by parties representing the preferences of individuals with sufficiently high marginal utilities of income and labor earning abilities below the nationwide average labor earning ability then the redistributive program of the central government induces all local governments to reduce the provision of public goods.

This is the case because public redistribution will provide a positive net transfer to the coalition of voters in control of local governments that induces this coalition to substitute the private good over the public good. Moreover, this effect could be large enough because low income voters are likely to show a high marginal utility of private consumption which also leads to a sufficiently low willingness to pay for local public goods (that is $\left.\exists \theta, \varepsilon,\left\{\alpha^{Z i}\right\}_{\forall n^{i}} \in \mathbb{R}_{++}: \varepsilon \rightarrow 0, \theta \rightarrow 0 \wedge\left\{M R S_{g^{z i}-\alpha^{Z i}}\right\}_{\forall \alpha^{Z i}} \in \mathbb{R}_{+_{+}}:\left|M R S_{g^{Z i}-\alpha^{Z i}}-\theta\right|<\varepsilon\right)$. In this case, the redistributive program of the central government provides strong incentives for all local governments to reduce the provision of public goods.

Proposition 6 and 7 also highlight the relevance of the distribution of the population as a determinant of the success of the redistributive policy of the central government. To see this, consider the case in which the high income district is controlled by a party representing voters with sufficiently high marginal utilities of income and labor earning abilities below the nationwide average labor earning ability and the population in this economy is sorted unevenly in a way in which a small density of the population of the country is living in the low income district. In this case, it is also simple to demonstrate that the redistributive policy of the government is likely to reduce the supply of local public goods in all districts.

The implication of these outcomes is that the attempt of the central government to redistribute welfare from the rich to the poor through public policy can be undermined by the response of local governments to the ex-post distribution of income engineered by the redistributive policy of the central government. (Note 12). As a result, the redistributive policy of the central government might cause significant inefficiency costs in the allocation of resources (due to the individuals' response to the tax and transfers policies) while the benefits in redistributing welfare might be limited due to the response of local governments in the provision of public goods.

\section{Conclusion}

While the benefit of public redistribution is a welfare superior allocation of resources for the society, it is well known that the deadweight social costs that arise from the behavioral responses of firms and households are central in determining the net effectiveness of the government's programs that seek to redistribute income and welfare. In this paper, we extend this literature by identifying political and economic conditions in which the benefits of redistributing income might also be limited by the response of local public spending to the ex-post distribution of income engineered by a linear redistributive program of the central government.

In this paper we develop a political economy model of a federation in which the central government redistributes income and local governments set commodity taxes to provide a pro poor local public good. In our economy, parties are political institutions that represent coalitions of voters who compete to form a local government to implement their ideal fiscal policies. This process of preference aggregation by parties is central to explain the response of local governments to the redistributive policy of the central government. In this setting, one outcome of interest is whether pro poor local public spending falls as a result of the redistributive policy of the central government. The implication of this outcome is that the attempt of the central government to redistribute welfare 
from the rich to the poor through a linear redistributive program could be ineffective.

Hence, our paper contributes to the literature on coordination failures in a federation by identifying conditions in which: first, a linear redistributive policy might fail to redistribute welfare in a focalized district and, second, the redistributive policy is universally ineffective in redistributing welfare in the federation. In particular, for the case of focalized ineffective redistribution, we identify that, if local public spending is pro poor, the party in office in some district $i$ represents a coalition of voters with labor earning abilities below the average earning ability of the economy and the aggregate net transfer from the redistributive program is negative for residents in this locality, then the size of local public spending in this district falls. In this case, redistribution increases the well being of poor familes but a fall in local spending reduces it leading to a net ambigous welfare effect of redistribution on poor households. For the case of universally ineffective redistribution, we identify that if local public spending is pro poor, local governments in all districts are controlled by parties representing voters with sufficiently high marginal utilities of income and labor earning abilities below the nationwide average earning ability then the redistributive program of the government induces all local governments to reduce local spending. It follows that the redistributive policy of the central government is universally ineffective in redistributing welfare in the federation. Finally, in this paper we also identify empirically verifiable hypothesis on the effects of a linear redistributive program of the central government on the spending policies of sub-national governments.

\section{References}

Alm, J. (1996). What is an optimal tax system? National Tax Journal, 49, 117-133.

Auerbach, A. J., \& Hines, J. R. Jr. (2002). Taxation and economic efficiency. In Auerbach A. J. \& Feldstein, M. (Eds.), Handbook of Public Economics (Vol. 3, pp. 1348-1416). Amsterdan: Elsevier Science. http://dx.doi.org/10.1016/S1573-4420(02)80025-8

Auerbach, A. J., \& Slemrod, J. (1997). The economic effects of the tax reform act of 1986. The Journal of Economic Literature, 35, 589-632.

Boadway, R., \& Keen, M. (1996). Efficiency and the optimal direction for federal-state transfers. International Tax and Public Finance, 3, 137-155. http://dx.doi.org/10.1007/BF00399907

Dahlby, B., \& Wilson, L. S. (1994). Fiscal capacity, tax effort, and optimal equalization grants. Canadian Journal of Economics, 27, 657-672. http://dx.doi.org/10.2307/135789

Dahlby, B., \& Wilson, L. S. (2003). Vertical fiscal externalities in a federation. Journal of Public Economics, 87, 917-930. http://dx.doi.org/10.1016/S0047-2727(01)00137-2

Gravelle, J. G., \& Kotlikoff, L. J. (1989). The incidence and efficiency effects of corporate taxation when corporate and noncorporate firms produce the same good. Journal of Political Economy, 97, 749-780. http://dx.doi.org/10.1086/261627

Johnson, W. R. (1988). Income redistribution in a federal system. American Economic Review, 78, 570-573.

Roemer, J. E. (1997). Political-economic equilibrium when parties represent constituents: The unidimensional case. Social Choice and Welfare, 14, 479-502. http://dx.doi.org/10.1007/s003550050082

Roemer, J. E. (2001). Political competition theory and applications. Cambridge, Massachusetts: Harvard University Press.

Salanié, B. (2003). The economics of taxation. Cambridge, Massashusetts: MIT Press.

Ter-Minassian, T. (1997). Fiscal federalism in theory and practice. Washington, DC: International Monetary Fund.

Wittman, D. A. (1973). Parties as utility maximizers. American Political Science Review, 67, 490-498. http://dx.doi.org/10.2307/1958779

Wittman, D. A. (1983). Candidate motivation: A synthesis of alternative theories. The American Political Science Review, 77, 142-157. http://dx.doi.org/10.2307/1956016

\section{Notes}

Note 1 . The private purchases are given by the Marshallian demand $x^{* i}\left(t^{i}, \tau, T, n^{i}\right)$ defined by $x^{* i}\left(t^{i}, \tau, T, n^{i}\right) \in$ $\operatorname{argmax}\left\{\mu^{i}\left(x^{i},\left(1-\ell^{i}\right), g^{i}\right)\right.$ subject to $\left.q^{i} x^{i}=n^{i} \ell^{i}(1-\tau)+T\right\}$.

Note 2. For some applications of this view of the political process to the analysis of public finance see Roemer (1997, 2001).

Note 3. In this paper we provide a comparative static analysis only for the case in which public redistribution 
does not lead to a change of the party that holds office. We leave the analysis of the impact of the redistributive policy of the central government on party regime for future analysis.

Note 4. In our economy all citizens vote and voting is sequentially rational.

Note 5. In our economy there is complete information about the parties' types. Hence there is no gain for parties to hide their true preferences over feasible local public spending. This means that parties have no incentives to announce the median voter policy in each locality in the second scenario while implementing the parties' ideal size of public spending in the fourth scenario (this issue is better known as the dynamic inconsistency problem).

Note 6 . The coalition of voters that control the party has a net gain from the redistributive program of the central government if $T-\tau n^{Z i}>0$.

Note 7. For simplicity of the analysis we assume that in the event $\boldsymbol{\Omega}\left(\forall n^{i} \in\left[n_{\min }^{i}, n_{\max }^{i}\right]: \chi^{i}\left(n^{i}\right)<0\right)=1 / 2$ then nature flips a coin and the party winning the bet takes control of the government.

Note 8. To see that $n^{R i}>n^{L i}, \alpha^{R i}<\alpha^{L i} \Leftrightarrow \alpha^{R i} n^{R i}>\alpha^{L i} n^{L i}$ start at $\left\{1 / n^{R i}<1 / n^{L i}\right\} \Rightarrow\left\{T / n^{R i}<\right.$ $\left.T / n^{L i}\right\}$ and then add $(1-\tau)$ to show $\left\{(1-\tau)+\frac{T}{n^{R i}}<(1-\tau)+\frac{T}{n^{L i}}\right\}$ which is equivalent to $\frac{n^{L i}}{(1-\tau) n^{L i}+T}<$ $\frac{n^{R i}}{(1-\tau) n^{R i}+T}$. Now multiply both sides by $2 q^{i} / q^{i}$ hence $\frac{1}{q^{i}}\left\{\frac{2 q^{i} n^{R i}}{(1-\tau) n^{R i}+T}\right\}>\frac{1}{q^{i}}\left\{\frac{2 q^{i} n^{L i}}{(1-\tau) n^{L i}+T}\right\}$ which means $\left\{\frac{n^{R i}}{q^{i} x^{* R i}}\right\}>\left\{\frac{n^{L i}}{q^{i} x^{* L i}}\right\}$ since by proposition $1 x^{* Z i}=\frac{n^{Z i}(1-\tau)}{2 q^{i}}+\frac{T}{2 q^{i}} \forall Z$. By the first order conditions of the individual's choice problem $\alpha^{Z i}=\frac{1}{q^{i} x^{* Z i}} \forall Z$. Therefore, $\left\{\frac{n^{R i}}{q^{i} x^{* R i}}\right\}>\left\{\frac{n^{L i}}{q^{i} x^{* L i}}\right\} \Rightarrow \alpha^{R i} n^{R i}>\alpha^{L i} n^{L i}$.

Note 9. This is the case if we normalize values of $\mu^{i}=1, \ell^{i}=1$ and $\tau=0$.

Note 10. It is simple to see this. An individual in district $i$ with a labor earning ability of $n^{i}$ receives a net positive transfer from the redistributive program of the central government if $T-\tau n^{i} \ell^{* i}\left(\tau, T, n^{i}\right)>0$. Use condition (3) to show that $T-\tau n^{i} \ell^{* i}\left(\tau, T, n^{i}\right)>0$ is equivalent to $n^{i}<T[(2-\tau) / \tau(1-\tau)]$. Now from the budget constraint of the federal government $T=\tau \sum_{\forall i} \int_{\forall n^{i}} h^{i}\left(n^{i}\right) n^{i} \ell^{* i}\left(\tau, T, n^{i}\right) d n^{i}$. Use again (3) in the budget constraint of the government to show that $T=[\tau(1-\tau) /(2-\tau)] E[n]$ where $E[n]=\sum_{\forall i} \int_{\forall n^{i}} h^{i}\left(n^{i}\right) n^{i} d n^{i}$ is the average labor earning ability in the economy. Use this last expression into $n^{i}<T[(2-\tau) / \tau(1-\tau)]$ to show that an individual in district $i$ with a labor earning ability of $n^{i}$ receives a net positive transfer from the redistributive program of the central government when $n^{i}<E[n]$.

Note 11. This effect is formally characterized in proposition 6 by equation (6.1).

Note 12. This is the case because on the one hand the redistributive policy of the central government increases the full income, private consumption and the wellbeing of low wage earners. On the other hand, if the redistributive policy of the central government also reduces the supply of local public goods then the welfare of low wage earners also falls. 